\title{
Multiorganelle Localization of Metallated Phthalocyanine Photosensitizer in Colorectal Cancer Cells (DLD-1 and CaCo-2) Enhances Efficacy of Photodynamic Therapy
}

\author{
Palesa Rose Sekhejane, Nicolette Nadene Houreld, and Heidi Abrahamse \\ Laser Research Centre, Faculty of Health Sciences, University of Johannesburg, P.O. Box 17011, Doornfontein 2028, South Africa \\ Correspondence should be addressed to Heidi Abrahamse; habrahamse@uj.ac.za
}

Received 13 November 2013; Revised 12 January 2014; Accepted 26 January 2014; Published 3 March 2014

Academic Editor: Rudolf Steiner

Copyright (C) 2014 Palesa Rose Sekhejane et al. This is an open access article distributed under the Creative Commons Attribution License, which permits unrestricted use, distribution, and reproduction in any medium, provided the original work is properly cited.

Colorectal cancer is the third most commonly diagnosed cancer. Amongst treatments that have been explored, photodynamic therapy (PDT) is a treatment that is of interest as it poses ideal advantages such as affinity for cancer cells. This study aimed to determine the correlation between the localization site of a sulfonated zinc phthalocyanine $\left(\mathrm{ZnPcS}_{\text {mix }}\right)$ photosensitizer (PS) and its associated cell death pathway in vitro in colorectal cancer cell lines (DLD-1 and CaCo-2). Visible morphological changes were observed in PDT treated cells after $24 \mathrm{~h}$. Reactive oxygen species (ROS) were detected and visualized $1 \mathrm{~h}$ after PDT. ZnPcS ${ }_{\text {mix }}$ was predominantly localized in lysosomes and partially in the mitochondria. FITC Annexin V staining showed a significant decrease in the percentage of viable DLD- 1 and CaCo- 2 cells $24 \mathrm{~h}$ after PDT, with an increase in apoptotic cell population. Moreover, there was a significant increase in both cathepsin D and cytochrome $\mathrm{C}$ at 1 and $24 \mathrm{~h}$. In conclusion, $\mathrm{ZnPcS}_{\text {mix }}$ showed the ability of inducing apoptotic cell death features in PDT treated cells.

\section{Introduction}

Cancer is defined as a group of diseases that have an unbalanced rate between apoptosis and proliferation. Rapid multiplication of abnormal cells may be caused by various factors ranging from genetic to external factors such as chemicals or diet [1]. Colorectal cancer is amongst the top ranking cancers that have a high mortality rate worldwide [1]. It occurs as a result of genetic and epigenetic changes of normal glandular epithelial cells into invasive adenocarcinoma [2]. The treatment for colorectal cancer remains a challenge due to the high metastatic incidence and recurrence of the disease [3], as well as toxicity caused by chemotherapeutic drugs to noncancerous cells. Colectomy, chemotherapy and radiation are regarded as primary treatment methods. However, there are concerns that these treatments commonly result in poor quality of life, lower overall survival rate, and resistance to treatment $[4,5]$. Thus, it is essential to develop other therapeutic strategies that may potentially enhance the quality of life and eventually improve survival rate.
Photodynamic therapy (PDT) has been under investigation as an alternative treatment modality to adjuvant chemotherapy or chemoradiotherapy. PDT utilizes three components, namely, light with wavelengths ranging between 650 and $750 \mathrm{~nm}$, a photosensitive drug (referred to as a photosensitizer, PS) capable of intracellular localization, and molecular oxygen, which renders the modality effective [6]. It is a comparatively better modality than surgery, radiotherapy, and chemotherapy as it is a minimally invasive therapy. In addition to being a minimally invasive treatment, a good PS should possess a low dark (inactive) and administrative toxicity [7]. Additionally, a well-formulated PS has a high affinity for cancer cells due to the high content of low density lipoprotein (LDL) receptors in cancer cells which enhances uptake of the PS [8-10]. PDT is an ablative energy requiring process that utilizes natural or synthetic structures that are photosensitive and capable of absorbing energy in the form of light. Castano et al. [7] suggested that an ideal PS should absorb light in the red to near infrared spectra, 
as shorter wavelengths have lower tissue penetration capacity $[11,12]$.

Although PDT was discovered over a century ago, it is has become a field of interest with progressive developments and advances, especially with regard to the development of PSs. The photodynamic reaction occurs when the PS is activated by absorption of energy from light (at a specific wavelength) in the form of photons, thereby producing reactive oxygen species (ROS) which then result in the photodynamic reaction [13]. Light interaction with the PS is one of the most crucial factors that determine the efficacy of treatment [14]. The photodynamic reaction can occur via two known photochemistry pathways. The first pathway, usually termed Type I, produces free radicals and ROS through electron transfer between the PS triplet state and surrounding molecules. The Type II reaction produces singlet oxygen $\left({ }^{1} \mathrm{O}_{2}\right)$ through energy transfer from the PS ground state to surrounding oxygen molecules $[7,15]$. Both pathways can occur concurrently, although the ratio may depend on the type of PS, binding affinity of the substrate, and oxygen and substrate concentration. However, the Type II reaction is considered the most frequent pathway responsible for cell death [14, 16-18].

Oxidative stress caused by PDT is known to cause membrane lipid peroxidation or rupture and DNA damage that may lead to apoptosis or necrosis [19]. Apoptosis occurs through a series of intracellular and extracellular biochemical milieu. Lysosomes and mitochondria are vital membranous organelles that also play a role in cell death dynamics. PSs that target mitochondria have been thought to be more effective as opposed to those that localize in other organelles [20,21] as it is believed that they can induce apoptosis directly. However, lysosomal targeting PSs have also been emerging as good candidates [22, 23]. Lysosomes have an acidic environment and host hydrolases that have the potential to degrade proteins and the entire cell upon leakage [24]. Amongst wellstudied lysosomal hydrolases is cathepsin $\mathrm{D}$ which belongs to the aspartyl proteases [25]. Besides its catalytic role, cathepsin D also participates in apoptosis. When triggered by cytotoxic factors, depending on the environment, it can induce apoptosis or inhibit it [26, 27]. Permeabilization of the lysosomal membrane can be activated by oxidative stress which usually leads to mitochondrial outer membrane destabilization and caspase activation through spillage of its acidic contents or catalytic enzymes $[28,29]$. Subsequently, this may lead to leakage of cytochrome $\mathrm{C}$ from mitochondria into the cytosol and thus activate caspases.

Cellular uptake of the PS is a fundamental factor in order for the drug to be effective and its intracellular localization site may help understand the mode of cell death as molecular singlet oxygen may be primarily formed by PDT in that preferred organelle. Zinc phthalocyanines (ZnPcs) have desirable PDT application qualities as they are said to have an intensive absorption of light in the visible red region and high singlet and triplet production [30]. Barr et al. used an aluminium sulphonated phthalocyanine (AlSPc) for the treatment of dimethylhydrazine-induced colon cancer in Wistar rats. They reported a significant eradication of the colonic mucosa tumour with necrosis and further suggested that it may be useful as an adjunctive treatment as they doubt that PDT alone will have magnanimous effects for deep seated tumours such as colon cancer in vivo [31]. Woodhams et al. conducted a study using bacteriopherophorbide (Tookad) based photodynamic therapy (PDT) in the colonic mucosa of the Hooded Lister rats [32]. They reported short drug light interval as an advantage; however, the treatment induced necrosis accompanied by inflammatory response three days after PDT [32].

In this study, we sought to determine the correlation between the localization site of sulfonated zinc phthalocyanine $\left(\mathrm{ZnPcS}_{\text {mix }}\right)$ in colorectal cancer cells (DLD-1 and CaCo2) and mode of cell death induced after PDT.

\section{Materials and Methods}

2.1. Cell Culture. This research was approved by the Academic Ethics Committee of the Faculty of Health Sciences, University of Johannesburg, under ethics clearance number AEC81/2009. Commercially obtained colorectal cancer cells were used (CaCo-2 ATCC HTB-37 and DLD-1 ATCC CCL221). CaCo-2 cells were cultured in Dulbecco's modified Eagle's media (DMEM, Sigma-Aldrich, D6429) with $1.2 \mathrm{~g} / \mathrm{L}$ sodium carbonate, supplemented with $10 \%$ foetal bovine serum (FBS, Gibco, 306.00301), nonessential amino acids (NEAA, Gibco, 11140), $0.5 \mathrm{mM}$ sodium pyruvate (Gibco, 11360 ), $2.5 \mathrm{mM}$ L-glutamine (Gibco, 25030), 1\% antibiotic (penicillin-streptomycin, Gibco, 15140), and 1\% antifungal (amphotericin-B, Gibco, 104813). DLD-1 cells were cultured in Dulbecco's modified Eagle's media and Ham's nutrient mixture F-12 (DMEM/F12, Sigma-Aldrich, D6421), supplemented as for CaCo-2 cells. Cultures were maintained in $5 \% \mathrm{CO}_{2}$ and $85 \%$ humidity at $37^{\circ} \mathrm{C}$. Once cells reached $80-$ $90 \%$ confluence, they were harvested and seeded at a density of $5 \times 10^{4}$ in $3 \mathrm{~mL}$ media into sterile culture dishes, with a diameter of $3.4 \mathrm{~cm}$. Cells were allowed to attach overnight.

2.2. PDT Experiments. The $\mathrm{ZnPcS}_{\text {mix }}$ used in this study contained various sulfo groups that have been reported to enhance the solubility [33]. The photochemical and photophysical properties of the $\mathrm{ZnPcS}_{\text {mix }}$ in phosphate buffered saline (PBS) were determined at the Department of Chemistry, Rhodes University, South Africa. $\mathrm{ZnPcS}_{\text {mix }}$ had a fluorescence quantum yield $\left(\Phi_{F}\right)$ of 0.16 ; triplet quantum yield $\left(\Phi_{T}\right)$ of 0.53 ; singlet oxygen quantum yield $(\Phi \Delta)$ of 0.45 , and triplet lifetime $\left(\tau_{T}\right)$ of $2.95 \mu$ s [33]. Cells were divided into three control groups: untreated cells, that is, cells that neither received irradiation nor PS, cells receiving laser irradiation alone $\left(5 \mathrm{~J} / \mathrm{cm}^{2}\right)$, and cells receiving PS alone $\left(\mathrm{ZnPcS}_{\text {mix }}\right)$ at a concentration of $20 \mu \mathrm{M}$. The test group received both PS and irradiation (PDT). Cells that did not receive laser irradiation were sham irradiated. After cells had attached, they were rinsed in Hank's Balanced Salt Solution (HBSS, Invitrogen, $10-543 \mathrm{~F}$ ) and fresh media were added to a volume of $1 \mathrm{~mL}$ before the addition of $\mathrm{ZnPcS}_{\text {mix }}$ or irradiation. Cells were irradiated in the dark from above in an open culture dish, using a continuous diode laser emitting light at a wavelength 
TABLE 1: Laser irradiation parameters.

\begin{tabular}{lc}
\hline Wavelength & $680 \mathrm{~nm}$ \\
Average power output & $42 \mathrm{~mW}$ \\
Light source & Diode \\
Illuminated area & $9.1 \mathrm{~cm}^{2}$ \\
Irradiance & $4.6 \mathrm{~mW} / \mathrm{cm}^{2}$ \\
Irradiation time & $18 \mathrm{~min} 6 \mathrm{~s}$ \\
Fluence & $5 \mathrm{~J} / \mathrm{cm}^{2}$ \\
Power meter & Coherent, fieldmate \\
\hline
\end{tabular}

of $680 \mathrm{~nm}$; cells were irradiated with a fluence of $5 \mathrm{~J} / \mathrm{cm}^{2}$, as it was determined optimum from dose response studies [34]. A combination of $20 \mu \mathrm{M} \mathrm{ZnPcS}$ mix and a fluence of $5 \mathrm{~J} / \mathrm{cm}^{2}$ was used based on the morphological changes that resembled apoptosis as well as loss of cell viability beyond $40 \%$ as discussed in Manoto et al. [34]. Laser irradiation parameters are tabulated in Table 1. Biological responses were evaluated after further incubation for 1 or $24 \mathrm{~h}$.

2.3. Cellular Morphology. The effect of the PS or PDT on cell morphology was determined using an inverted light microscope (Wirsam, Olympus CKX41). Once digital images were recorded, cells were trypsinized using $1 \mathrm{~mL} / 25 \mathrm{~cm}^{2}$ of TrypLE Express (Invitrogen, 12605-028) and resuspended in HBSS (unless otherwise specified) to perform further assays.

2.4. Reactive Oxygen Species (ROS) Detection. Oxidative stress caused by $\mathrm{ZnPcS}_{\text {mix }}$ when activated by laser light was shown qualitatively by fluorescent staining of the cells with carboxy- $\mathrm{H}_{2}$ DCFDA Reactive Oxygen Species detection kit (Invitrogen, Image-iT, I36007). Cells cultured on cover slips were washed with warm HBSS and covered with $25 \mu \mathrm{M}$ carboxy- $\mathrm{H}_{2} \mathrm{DCFDA}$ working solution and incubated for $30 \mathrm{~min}$ at $37^{\circ} \mathrm{C}$ in the dark. Thereafter, cells were washed three times with HBSS and nuclei were counterstained with $0.1 \mathrm{mg} / \mathrm{mL}$ of DAPI (4'-6-diamidino-2-phenylindole, SigmaAldrich, D9564) for $1 \mathrm{~min}$ and washed. The ROS positive control was prepared according to the protocol prescribed by the manufacturer. Briefly, ROS was induced in CaCo-2 cells by adding $100 \mu \mathrm{M}$ of tert-butyl hydroperoxide (TBHP) for duration of $1 \mathrm{~h}$ at $37^{\circ} \mathrm{C}$. Cells that received neither PDT treatment, nor TBHP, nor laser irradiation were used as negative controls. Cells were stained for ROS detection $1 \mathrm{~h}$ after PDT by following the same procedure as mentioned above. Fluorescence was visualized using a Carl Zeiss Axio observer Z1 fluorescent microscope. Production of oxidation by carboxy- $\mathrm{H}_{2}$ DCFDA was viewed using $459_{\mathrm{Ex}} / 529_{\mathrm{Em}}$ and DAPI $350_{\mathrm{Ex}} / 461_{\mathrm{Em}}$ filters.

2.5. Intracellular Localization of $Z n P c S_{m i x}$. Fluorescence imaging was used to determine intracellular localization of $\mathrm{ZnPcS}_{\text {mix }}$. Briefly, cells were cultured overnight on sterile cover slips placed in $3.4 \mathrm{~cm}$ diameter culture dishes. Cells were rinsed with warm HBSS before incubating with $1 \mu \mathrm{M}$ $\mathrm{ZnPcS}_{\text {mix }}$ in supplemented media for $1 \mathrm{~h}$. Localization sites of $\mathrm{ZnPcS}_{\text {mix }}$ were determined using fluorescent markers for intracellular organelles. For mitochondria, cells were stained with $50 \mathrm{nM}$ MitoTracker Green FM (Invitrogen, M7514) and $75 \mathrm{nM}$ LysoTracker Green DND-26 (Invitrogen, L7526) was used for lysosomes. Cells were then incubated for $15 \mathrm{~min}$ in the dark. Nuclei were counterstained with DAPI. Fluorescence was visualized using a Carl Zeiss Axio observer Z1 fluorescent microscope [34].

2.6. Lysosomal Cathepsin D. Lysosomal protease cathepsin $D$ was measured using an enzyme-linked immunosorbent assay (ELISA) kit (Biocombiotech, Cusabio Biotech, CSBE09221h). Standard, blank (media only), or supernatants from experimental cells were added to their respective wells to a final volume of $100 \mu \mathrm{L}$. The plate was then incubated for $2 \mathrm{~h}$ at $37^{\circ} \mathrm{C}$. Wells were aspirated and $100 \mu \mathrm{L}$ of biotinantibodyworking solution was added to each well and incubated for $1 \mathrm{~h}$ at $37^{\circ} \mathrm{C}$. Each well was aspirated and washed with washing buffer three times. Horseradish peroxide- (HRP-) avidin working solution was then added to each well, and the plate was incubated for $1 \mathrm{~h}$ at $37^{\circ} \mathrm{C}$. The plate was aspirated and washed three times and then tetramethylbenzidine (TMB) substrate was added and incubated for $30 \mathrm{~min}$ at $37^{\circ} \mathrm{C}$. Stop solution was added and the plate was read at $450 \mathrm{~nm}$ absorbance using the Victor 3 multilabel microplate reader (Perkin-Elmer).

2.7. Cytosolic Cytochrome C. Cytosolic human cytochrome C was measured by ELISA (Biocombiotech, eBioscience, BMS263/BMS263TEN). Cell lysates were prepared according to the manufacturer's protocol. Briefly, cells were centrifuged at $137 \times \mathrm{g}$ for $15 \mathrm{~min}$ and washed with cold PBS. Cells were then resuspended in lysis buffer at a concentration of $1.5 \times$ $10^{6}$ per $1 \mathrm{~mL}$ and incubated at room temperature for $1 \mathrm{~h}$ with gentle shaking $(10 \mathrm{rpm})$ using an orbital shaker (Labotech, Heidolph, Polymax 1040). Cells were then centrifuged at $200 \times \mathrm{g}$ for $15 \mathrm{~min}$. The supernatant was diluted 50 -fold in assay buffer. Wells were washed with $400 \mu \mathrm{L}$ of washing buffer prior to commencing. Samples and standards were added to their respective wells and biotin-conjugate was added. The plate was incubated at room temperature for $2 \mathrm{~h}$ and then washed as before. Streptavidin-HRP was added and incubated for $1 \mathrm{~h}$ at room temperature. Thereafter, the plate was washed and TMB substrate was added for approximately $10 \mathrm{~min}$ and the reaction was stopped. Absorbance was read at $450 \mathrm{~nm}$ using the Victor [3] multilabel microplate reader (Perkin-Elmer).

2.8. FITC Annexin $V$. To determine the mode of cell death (necrosis or apoptosis), FITC Annexin V stain was used and the fluorescence was read using a flow cytometer (FACSAria). FITC Annexin V was used in conjunction with propidium iodide (PI) vital stain for necrotic cells. Cells were stained by washing detached cells twice with cold PBS and resuspended in $500 \mu \mathrm{L}$ of $1 \mathrm{x}$ assay binding buffer. A volume of $100 \mu \mathrm{L}$ was transferred into a $5 \mathrm{~mL}$ culture tube and incubated with $5 \mu \mathrm{L}$ of FITC Annexin V and another $5 \mu \mathrm{L}$ of PI. Cells were mixed by vortexing and incubated for $5 \mathrm{~min}$ on ice away from direct light. Then $400 \mu \mathrm{L}$ of $1 \mathrm{x}$ binding buffer was added to all the 
samples and were analyzed on the FACSAria flow cytometer by reading 10000 events.

2.9. Statistical Analysis. Each experiment was repeated four times $(n=4)$. Biochemical assays were done in duplicate and an average of the results was used. Statistics were analyzed using the SigmaPlot software version 8.0 (Systat Software) and the mean, standard deviation, standard error, and significant changes were calculated. Student $t$-test and one-way ANOVA were performed to determine the statistical difference between the controls and the experimental group. Statistical differences are shown in graphs as $\left({ }^{*}\right) P<0.05,\left({ }^{* *}\right)$ $P<0.01$, and $\left(^{* * *}\right) P<0.001$ and dispersion bars represent standard error.

\section{Results and Discussion}

3.1. Cellular Morphology. Control cells did not show any morphological changes at both 1 and $24 \mathrm{~h}$ incubation periods (Figure 1). After $1 \mathrm{~h}$ incubation, morphology of PDT treated CaCo-2 cells appeared altered as compared to control cells. PDT treated cells appeared less uniform with loss of membrane integrity, although still intact; this was not observed in the DLD-1 cell line. Furthermore, after $24 \mathrm{~h}$ significant changes were noticed whereby cells appeared pyknotic, intact membrane, and condensed nuclei. Some cells had detached from the culture plate and lost their original morphological features compared to those incubated for $1 \mathrm{~h}$ and the control cells.

We have previously shown that DLD-1 colorectal cancer cells are sensitive to $\mathrm{ZnPcS}_{\text {mix }}$ alone and PDT using the same PS [34]. The morphological features of DLD-1 and CaCo2 control cells (untreated; $5 \mathrm{~J} / \mathrm{cm}^{2}$ or $\mathrm{ZnPcS}_{\text {mix }}$ ) remained unchanged. However, morphological changes in the cells that received PDT treatment resembled that of apoptotic features as seen by the cells detaching from the culture dish surface, cellular shrinking, and an intact membrane [34]. Nonetheless, based on these morphological findings, it is not conclusive that the cells were definitely undergoing apoptosis.

3.2. Reactive Oxygen Species (ROS) Detection. ROS such as hydroxyl radicals $\left({ }^{\circ} \mathrm{OH}\right)$ and hydrogen peroxide $\left(\mathrm{H}_{2} \mathrm{O}_{2}\right)$ are normally generated in small amounts in cellular organisms due to aerobic metabolism [34]. However, oxidative stress caused by increased ROS concentration is known to cause cellular damage, and ROS induction has also been implicated in apoptosis $[35,36]$. ROS were detected in both cell lines that were treated with PDT as shown by distinct green fluorescence in the cytoplasm (Figure 2). PDT treated cells showed ROS fluorescence intensity similar to that of the positive control, thus proving that there was photooxidation after PDT. Based on this observation, we could anticipate that cell damage will follow eventually as ROS are known to kill cells by oxidizing lipid membranes and biomolecules [37, 38]. This was shown by the time dependent loss of cellular viability seen in PDT treated cells resulting in more than $40 \%$ cell death [34].
3.3. Intracellular Localization of $Z n P c S_{\text {mix }}$. It is known that the localization site of a PS is of importance as it is indicative of where the initial damage will occur [20, 39]. When cells were visualized using fluorescent microscopy, $\mathrm{ZnPcS}_{\text {mix }}$ predominantly localized in the lysosomes and to a lesser extent in the mitochondria (Figure 3).

Kessel and Luo deduced from their research that subcellular localization of the PS is a primary determinant of the cell death mechanism in PDT. Since the PS used in this study localizes predominantly in lysosomes and minimally in mitochondria, it is suggestive that $\mathrm{ZnPcS}_{\text {mix }}$ has chemical properties or charge that target both lysosomes and mitochondria [40]. A study conducted by Kessel and Luo used two $\mathrm{Zn}$ based phthalocyanine PSs in human cervical squamous carcinoma (HeLa) and murine colon adenocarcinoma (CT26) cells; one was cationic and the other was anionic [41]. The cationic porphyrin PS was more effective than the anionic PS as the former localized in both lysosomes and mitochondria. They further reported enhanced efficacy at concentrations between 2 and $10 \mu \mathrm{M}$ for the cationic PS and 10 and $50 \mu \mathrm{M}$ for the anionic PS, both activated at a fluence of $10 \mathrm{~J} / \mathrm{cm}^{2}$. However, CT26 cells were not sensitive enough to the initial concentration of $5 \mu \mathrm{M}$ cationic PS that was activated with $20 \mathrm{~J} / \mathrm{cm}^{2}$, although HeLa cells were sensitive [41]. Since our results coincide with Mroz et al.s results, it may be suggested that the PDT of colon adenocarcinoma using phthalocyanines may require high dosage in order to render the therapy beneficial, provided that the PS has significantly low dark toxicity.

3.4. Lysosomal Cathepsin D. At both time points, cathepsin $\mathrm{D}$ in DLD-1 and CaCo- 2 cells that received irradiation alone $\left(5 \mathrm{~J} / \mathrm{cm}^{2}\right)$ did not result in significant changes when compared to untreated control cells, Table 2 . After $1 \mathrm{~h}$ incubation, cathepsin D release was significantly increased in DLD-1 cells incubated with $\mathrm{ZnPcS}_{\text {mix }}$ alone $(P<0.05)$ or those that received $\mathrm{PDT}(P<0.01)$ in comparison to untreated control cells. A significant change was also noted in CaCo- 2 cells that received PDT compared to controls that were untreated or irradiated $\left(5 \mathrm{~J} / \mathrm{cm}^{2}\right)(P<0.01)$ and those that received $\mathrm{ZnPcS}_{\text {mix }}$ alone $(P<0.05)$ after $1 \mathrm{~h}$ incubation. Comparing cathepsin D in PDT treated DLD-1 and CaCo-2 cells after $1 \mathrm{~h}$ incubation revealed a significant increase in CaCo-2 cells $(P<0.05)$.

After $24 \mathrm{~h}$, both DLD-1 and CaCo-2 PDT treated cells had a significant increase in cathepsin $\mathrm{D}$ release $(P<0.001)$ when compared to all control cells (untreated, $5 \mathrm{~J} / \mathrm{cm}^{2}$ and $\mathrm{ZnPcS}_{\text {mix }}$ ). Additionally, after $24 \mathrm{~h}, \mathrm{ZnPcS}_{\text {mix }}$ alone induced a significant increase in cathepsin $\mathrm{D}$ release in CaCo- 2 cells when compared to cells that received irradiation alone $(P<$ 0.05). Cathepsin D release in PDT treated DLD-1 cells had significantly increased after $24 \mathrm{~h}$ incubation in comparison to $1 \mathrm{~h}$ incubation $(P<0.01)$. Moreover, there was a significant difference between DLD-1 and CaCo-2 PDT treated cells after 24 h incubation $(P<0.05)$.

Assuming that a high concentration of ROS is formed around the lysosomes, increased amounts of $\mathrm{H}_{2} \mathrm{O}_{2}$ can 

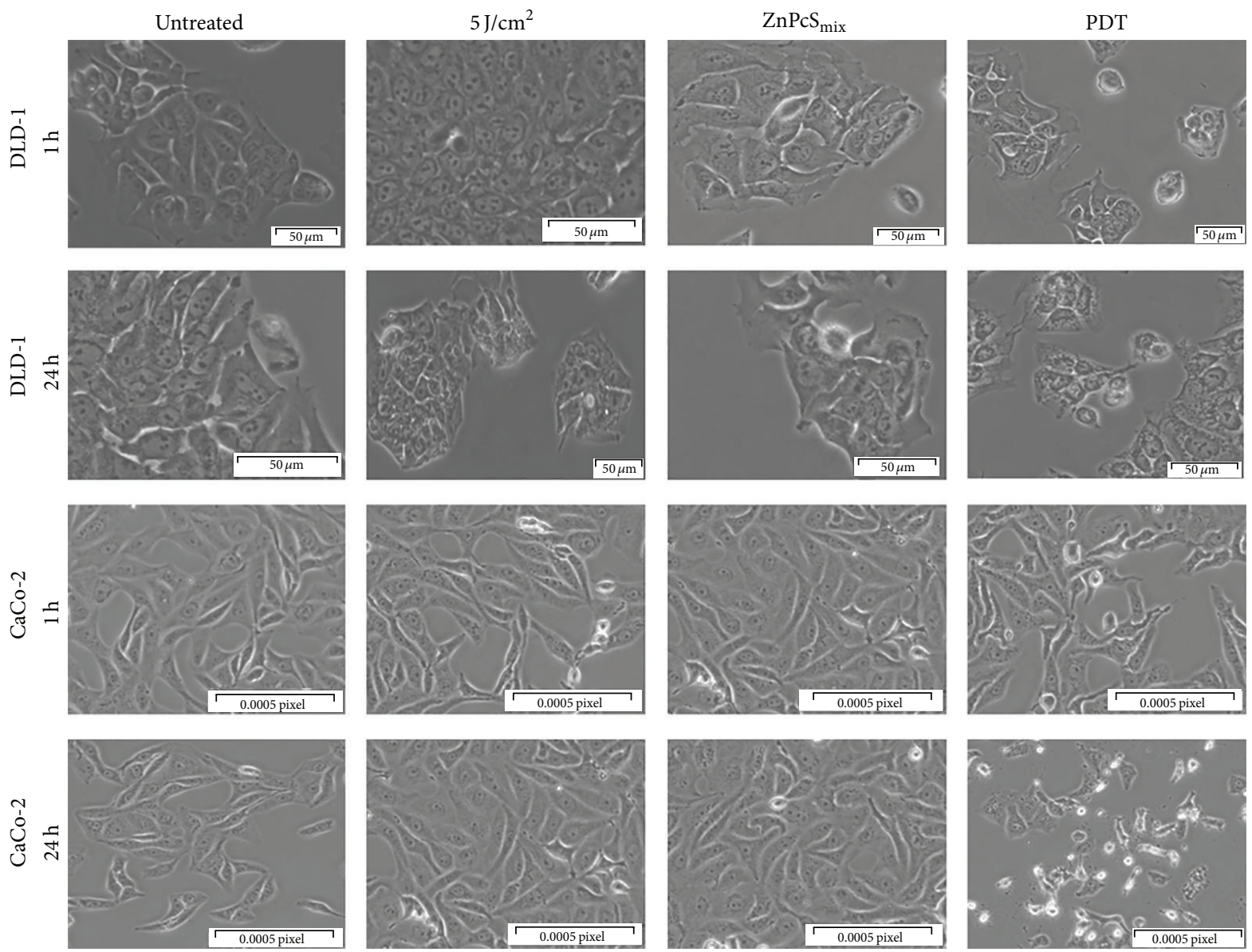

FIgure 1: Morphology of DLD-1 and CaCo- 2 cells after 1 or $24 \mathrm{~h}$ after PDT. After $1 \mathrm{~h}$ incubation after PDT, there were no significant visible differences in both DLD-1 and CaCo-2 cells, but, to some extent, cells showed membranal irregularity. After $24 \mathrm{~h}$ incubation, PDT cells appeared shrunken and rounded and had detached.

diffuse into lysosomes and react with intralysosomal metalloproteins (iron containing proteins) that have degraded as a result of acidic $\mathrm{pH}$. Iron is then reduced and hydroxyl radicals are formed which promote lipid peroxidation, causing leakage of lysosomal contents [42]. Therefore, perhaps the cell death mechanism induced in the DLD-1 and CaCo-2 cells after PDT could primarily be initiated from lysosomes. Mroz et al. reported that lysosomal membrane destabilization is an early event in apoptosis as compared to mitochondrial membrane destabilization [43]. However, even if photodamage is initiated in the lysosomes, the mitochondrial pathway is responsible for cell death as the activation of Bid is as a result of lysosomal protease release as hypothesized by Kurz and colleagues, in their study that also used a phthalocyanine PS that localized in lysosomes [44]. Our findings are in accordance with Kurz and colleagues' findings [44].

Based on the localization pattern of the $\mathrm{ZnPcS}_{\text {mix }}$, we determined that there was a proteolytic release of lysosomal aspartate cathepsin $\mathrm{D}$, which is associated with cell death [45]. Oxidative stress can directly disrupt the lysosomal membrane. It has been hypothesized that limited release of lysosomal contents can trigger apoptosis or apoptosis-like cell death as opposed to generalized membrane rupture which may cause necrosis $[46,47]$. In our study we found that there was a significant release of cathepsin D in both PDT treated cell lines especially after $24 \mathrm{~h}$ incubation. However, $\mathrm{ZnPcS}_{\text {mix }}$ alone also induced a significant leakage of the aspartic enzyme after $1 \mathrm{~h}$ incubation in DLD-1 cells and $24 \mathrm{~h}$ in CaCo- 2 cells in comparison to sham irradiated control cells, although it was to a lesser extent. This could be due to the prolonged incubation with the PS which may eventually lead to osmotic stress and can trigger membrane permeabilization [37].

3.5. Cytosolic Cytochrome C. Relocation of mitochondrial cytochrome $\mathrm{C}$ to the cytosol was quantitatively determined by ELISA in order to investigate mitochondrial membrane destabilization, as it is a hallmark of apoptosis. DLD-1 cells exposed to $\mathrm{ZnPcS}_{\text {mix }}$ alone proved to be susceptible to the photosensitizer at a concentration of $20 \mu \mathrm{M}$, and there was a significant increase in cytochrome $\mathrm{C}$ when compared to untreated control cells after $1 \mathrm{~h}$ incubation $(P<0.001)$, Table 2. There was a significant relocation of cytochrome $\mathrm{C}$ to the cytosol in PDT treated DLD-1 and CaCo-2 cells at both 1 and $24 \mathrm{~h}$ incubation $(P<0.001)$ when compared to all the control groups. Comparison of the incubation times 
DAPI
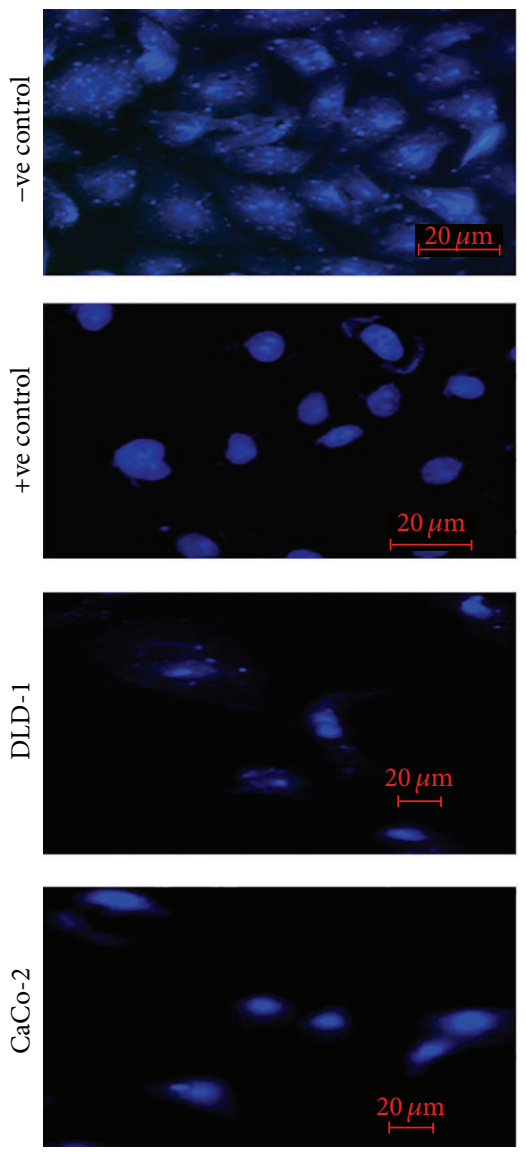

DCFDA
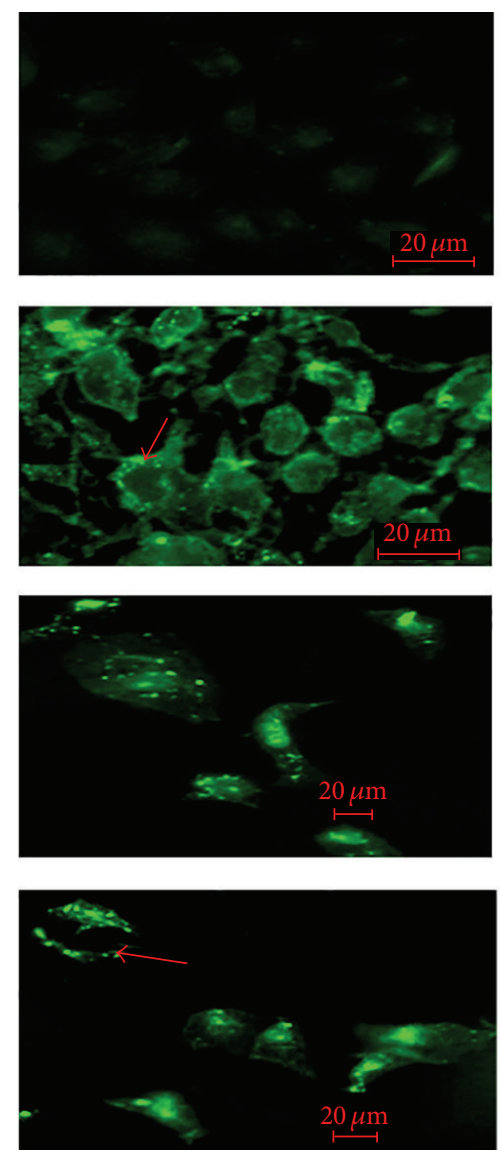

Merged
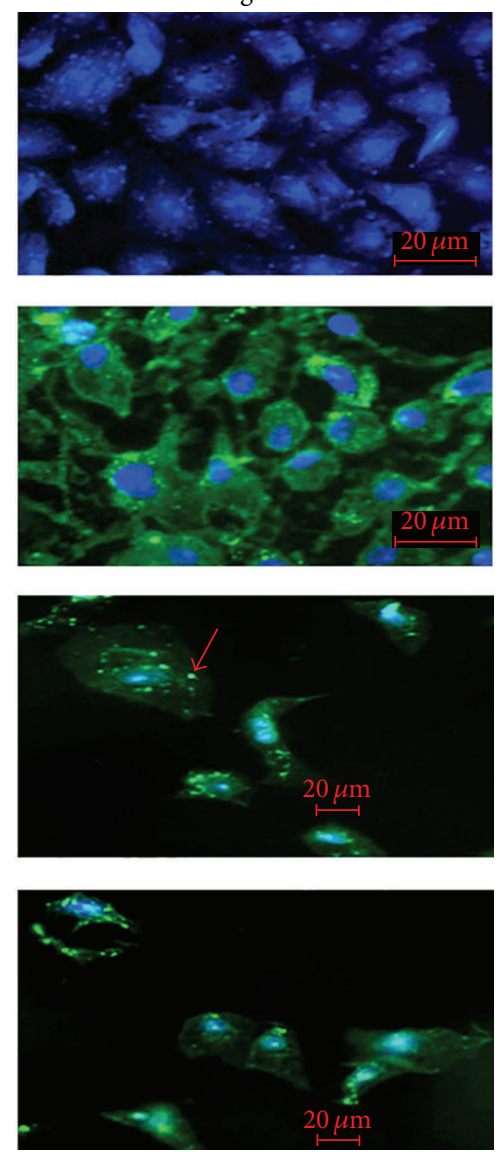

FIGURE 2: ROS production was qualitatively detected by staining cells with carboxy- $\mathrm{H}_{2}$ DCFDA which appears as green fluorescence if present as pointed out by the arrows. Nuclei were counterstained with DAPI (blue).

showed that there was a significant increase $(P<0.01)$ in cytochrome $\mathrm{C}$ in PDT treated cells (DLD-1 and CaCo-2) at $24 \mathrm{~h}$ compared to $1 \mathrm{~h}$. When DLD-1 and CaCo- 2 cells that were incubated with $\mathrm{ZnPcS}_{\text {mix }}$ alone were compared after $1 \mathrm{~h}$ incubation, there was a significant difference $(P<0.05)$ in cytochrome $\mathrm{C}$ release. However, the difference was not seen after $24 \mathrm{~h}$ incubation.

These results are in agreement with the cathepsin D results, denoting that the mitochondrial membrane is destabilized by lysosomal enzymes. This is supported by the idea proposed by Brunk and Svensson that lysosomal proteases can cause direct detrimental damage to the mitochondrial membrane [48]. The release of cytochrome $\mathrm{C}$ is believed to be an important event in PDT induced apoptosis as a result of ROS damage produced at the localization site $[49,50]$.

3.6. FITC Annexin V. There was a significant increase in the number of apoptotic DLD-1 cells as compared to the viable population $1 \mathrm{~h}$ after PDT $(P<0.001)$, Figure $4(\mathrm{a})$. Incubation of DLD-1 cells $24 \mathrm{~h}$ after PDT also showed a significant increase in apoptotic cells as compared to the viable and necrotic population $(P<0.001)$. Similarly, a significant increase was also seen compared to the apoptotic population in control cells $(P<0.001)$. There was a significant decrease in the percentage of viable PDT treated CaCo-2 cells after $1 \mathrm{~h}$ incubation as compared to the same cell population in control cells $(P<0.001)$, Figure $4(\mathrm{~b})$. When the apoptotic population in PDT treated CaCo- 2 cells was compared to the viable and necrotic population within the same group, there was a significant increase in apoptosis at 1 and $24 \mathrm{~h}$ after PDT incubation $(P<0.001)$.

Incubation with PS alone appeared to be a crucial factor for cell toxicity, as longer incubation periods may have resulted in unnecessary toxicity, rendering dosimetry a fundamental component of the treatment of colorectal cancer. This was proven otherwise by the FITC Annexin V results which showed that $\mathrm{ZnPcS}_{\text {mix }}$ in its inactive form was ineffective in inducing necrotic or apoptotic cell death as there was a fair amount of dead cells similar to untreated control cells. Activation of $\mathrm{ZnPcS}_{\text {mix }}$ potentially resulted in cell death and confirmed that the prevailing mode of cell death after PDT was apoptosis. Our results suggest that the apoptotic cell death pathway is initiated by lysosomes which prompts delayed mitochondrial cytochrome $\mathrm{C}$ leakage as induced by the proteolytic enzyme cathepsin $\mathrm{D}$ as well as the low $\mathrm{pH}$ from lysosomes in response to PDT. Moreover, it is possible that the mitochondrial membrane could be directly destabilized 

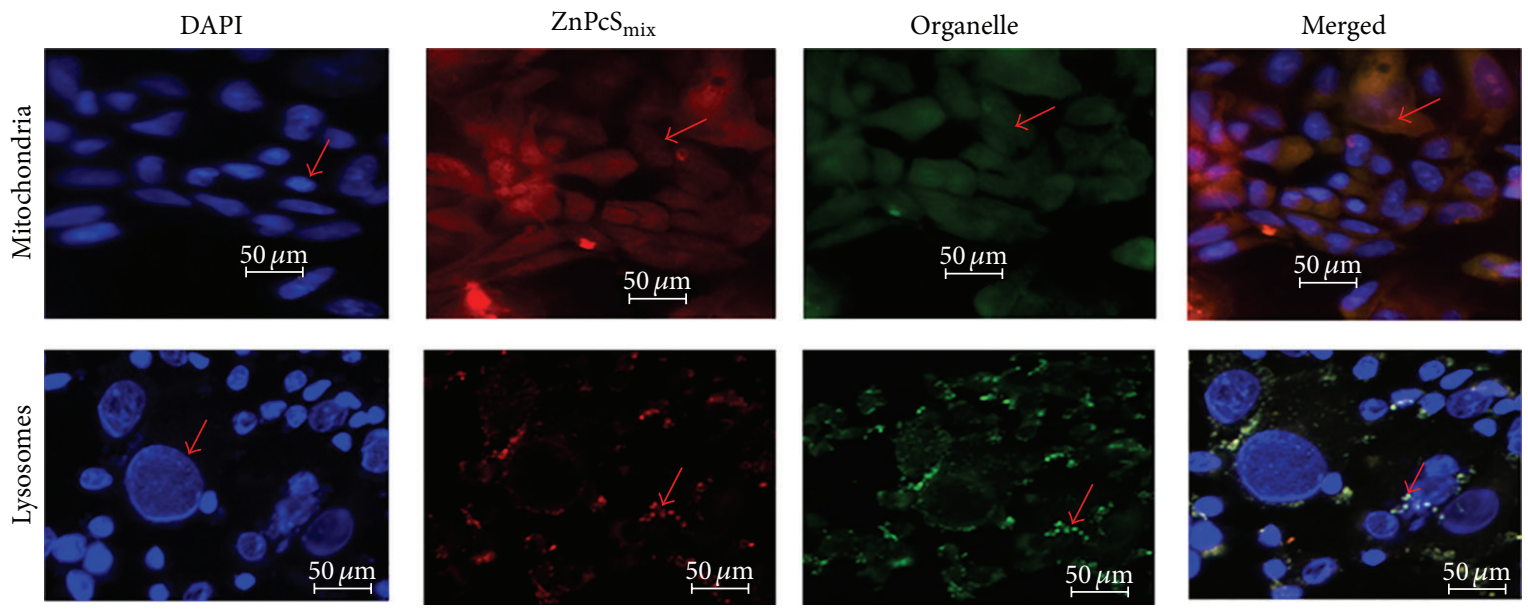

(a)
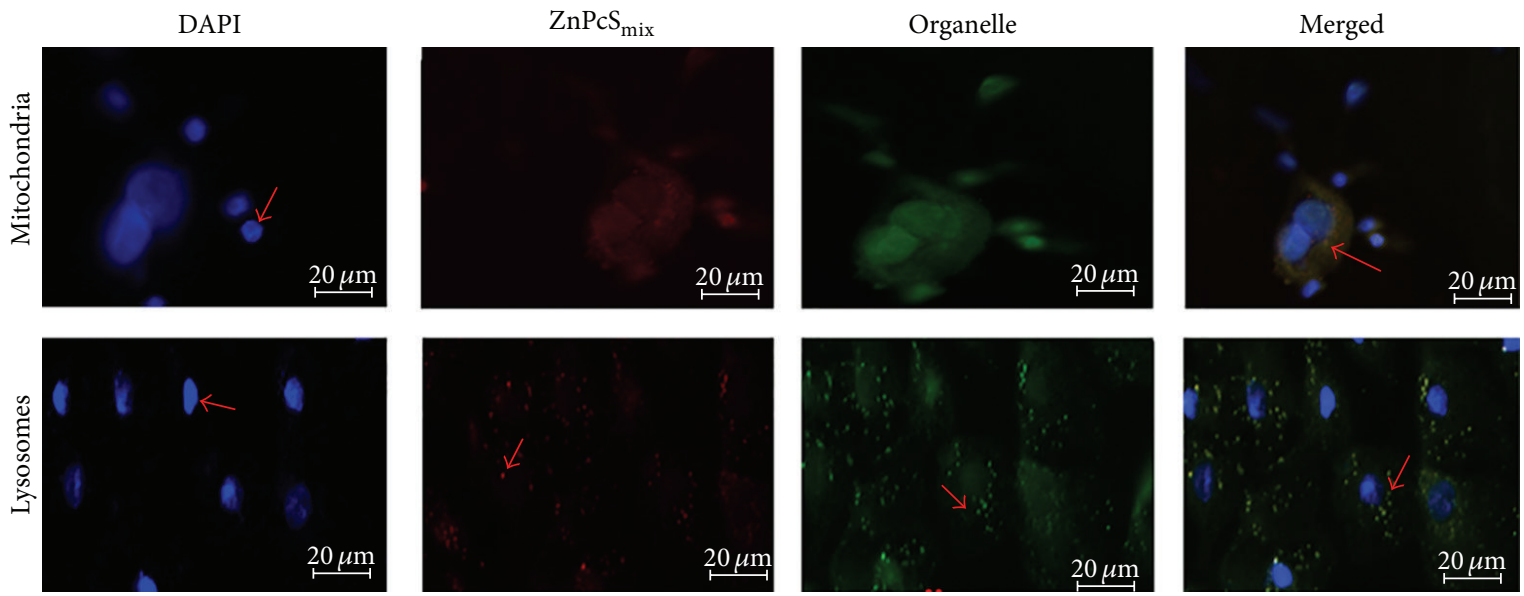

(b)

Figure 3: Intracellular localization of $\mathrm{ZnPcS}_{\text {mix }}$ PS in DLD-1 and CaCo-2 cells. PS localized in lysosomes in both cell lines as seen by the merging red and green colours as pointed out by the arrows. In mitochondria, there was an indefinite localization pattern. However, the orange colour meant that there was PS in mitochondria, as pointed out by the arrows. Nuclei were stained with DAPI (blue).

TABLe 2: Cathepsin D and cytosolic cytochrome C were measured after 1 and $24 \mathrm{~h}$ incubation after PDT. Significant differences shown in the table represent comparison between PDT treated cells and their respective untreated control cells after 1 or $24 \mathrm{~h}$ incubation $\left({ }^{*} P<0.05\right.$; ${ }^{* *} P<0.01$, and $\left.{ }^{* * *} P<0.001\right)$. Cathepsin D was significantly increased in DLD-1 $(P<0.01)$ and CaCo-2 $(P<0.05)$ after $24 \mathrm{~h}$ incubation in comparison to after $1 \mathrm{~h}$ incubation. In both cell lines, cytochrome $\mathrm{C}$ was significantly increased after $24 \mathrm{~h}$ incubation as compared to $1 \mathrm{~h}$ incubation $(P<0.01)$.

\begin{tabular}{lccccccccc}
\hline \multirow{2}{*}{ Assay } & \multirow{2}{*}{ Time } & \multicolumn{2}{c}{ Untreated } & \multicolumn{2}{c}{$5 \mathrm{~J} / \mathrm{cm}^{2}$} & \multicolumn{2}{c}{ ZnPcS $_{\text {mix }}$} & \multicolumn{2}{c}{ PDT } \\
& & DLD-1 & CaCo-2 & DLD-1 & CaCo-2 & DLD-1 & CaCo-2 & DLD-1 & CaCo-2 \\
\hline \multirow{2}{*}{ Cath-D } & $1 \mathrm{~h}$ & $0.05^{\mathrm{a}} \pm 1.16^{\mathrm{b}}$ & $0.06 \pm 2.84$ & $0.06 \pm 2.52$ & $0.06 \pm 1.78$ & $0.06^{*} \pm 9.76$ & $0.07^{*} \pm 2.28$ & $0.07^{*} \pm 3.82$ & $0.08^{* *} \pm 4.31$ \\
& $24 \mathrm{~h}$ & $0.06 \pm 2.39$ & $0.07 \pm 1.31$ & $0.06 \pm 3.03$ & $0.06 \pm 9.38$ & $0.07 \pm 5.12$ & $0.07 \pm 2.02$ & $0.10^{* * *} \pm 2.78$ & $0.09^{* * *} \pm 3.89$ \\
\hline \multirow{2}{*}{ Cyto-C } & $1 \mathrm{~h}$ & $0.10 \pm 2.194$ & $0.24 \pm 0.15$ & $0.12 \pm 0.02$ & $0.11 \pm 0.01$ & $0.20^{* * *} \pm 0.03$ & $0.11 \pm 0.02$ & $2.41^{* * *} \pm 0.12$ & $2.22^{* * *} \pm 0.18$ \\
& $24 \mathrm{~h}$ & $0.09 \pm 4.33$ & $0.09 \pm 4.57$ & $0.12 \pm 0.01$ & $0.09 \pm 5.47$ & $0.27 \pm 0.09$ & $0.14 \pm 0.02$ & $3.14^{* * *} \pm 0.22$ & $3.05^{* * *} \pm 0.22$ \\
\hline
\end{tabular}

${ }^{\mathrm{a}}$ Mean; ${ }^{\mathrm{b}}$ standard error of mean (SEM).

by ROS that are formed immediately at the localization site and the acidic milieu from the lysosomal compartments. Furthermore, the fact that $\mathrm{ZnPcS}$ mix activation can induce lysosomal rupture, thereby releasing cathepsin $\mathrm{D}$, renders $\mathrm{ZnPcS}_{\text {mix }}$ an interesting and effective PS since it can localize in two vital organelles. Work conducted by Oleinick's group also affirmed that the lysosomal targeted phthalocyanine PSs (Pc181) was surprisingly effective as opposed to the mitochondrial targeted PSs [39].

It is not clear from these results which subcellular organelle can be held responsible for cell death initiation, so further work needs to be conducted to determine which 

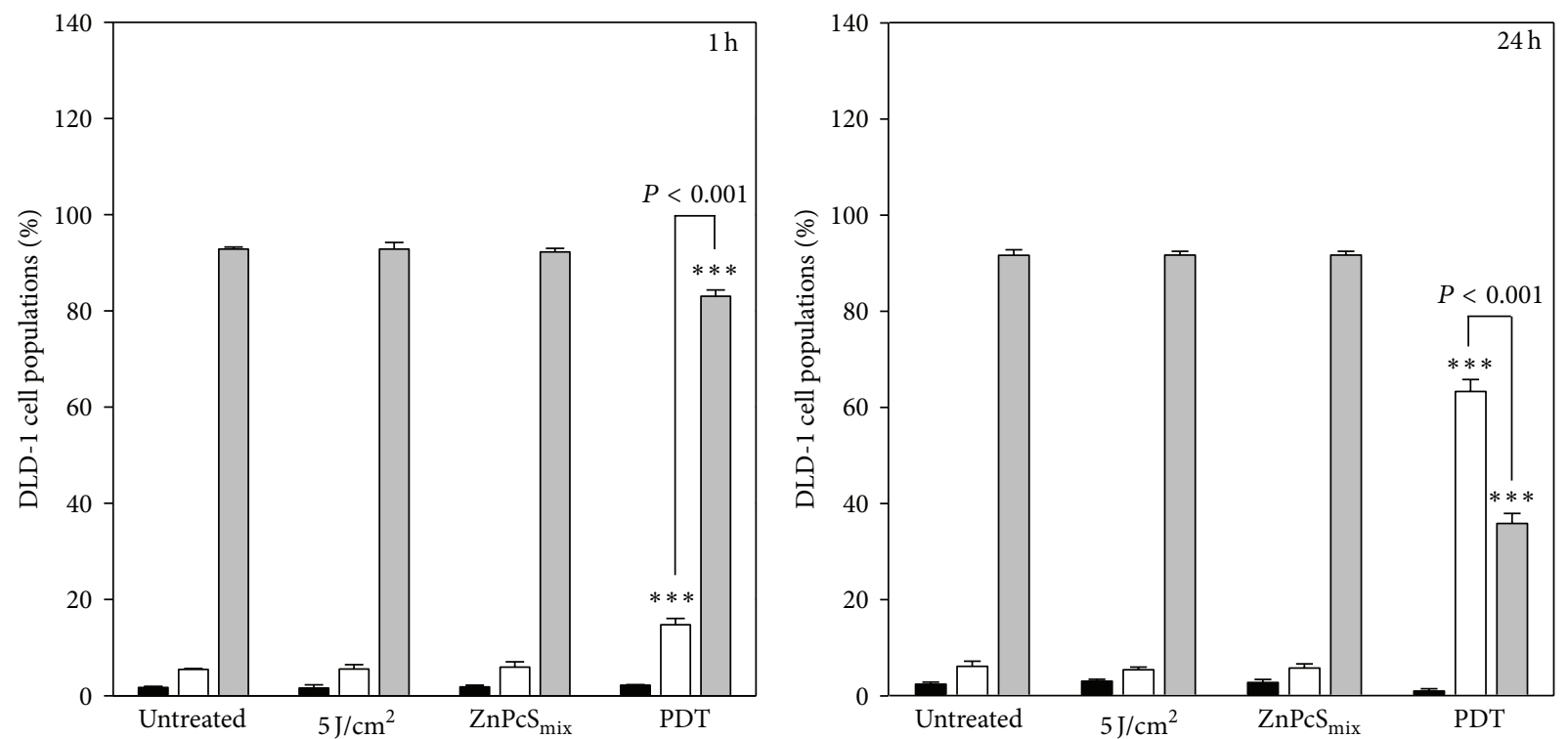

(a)
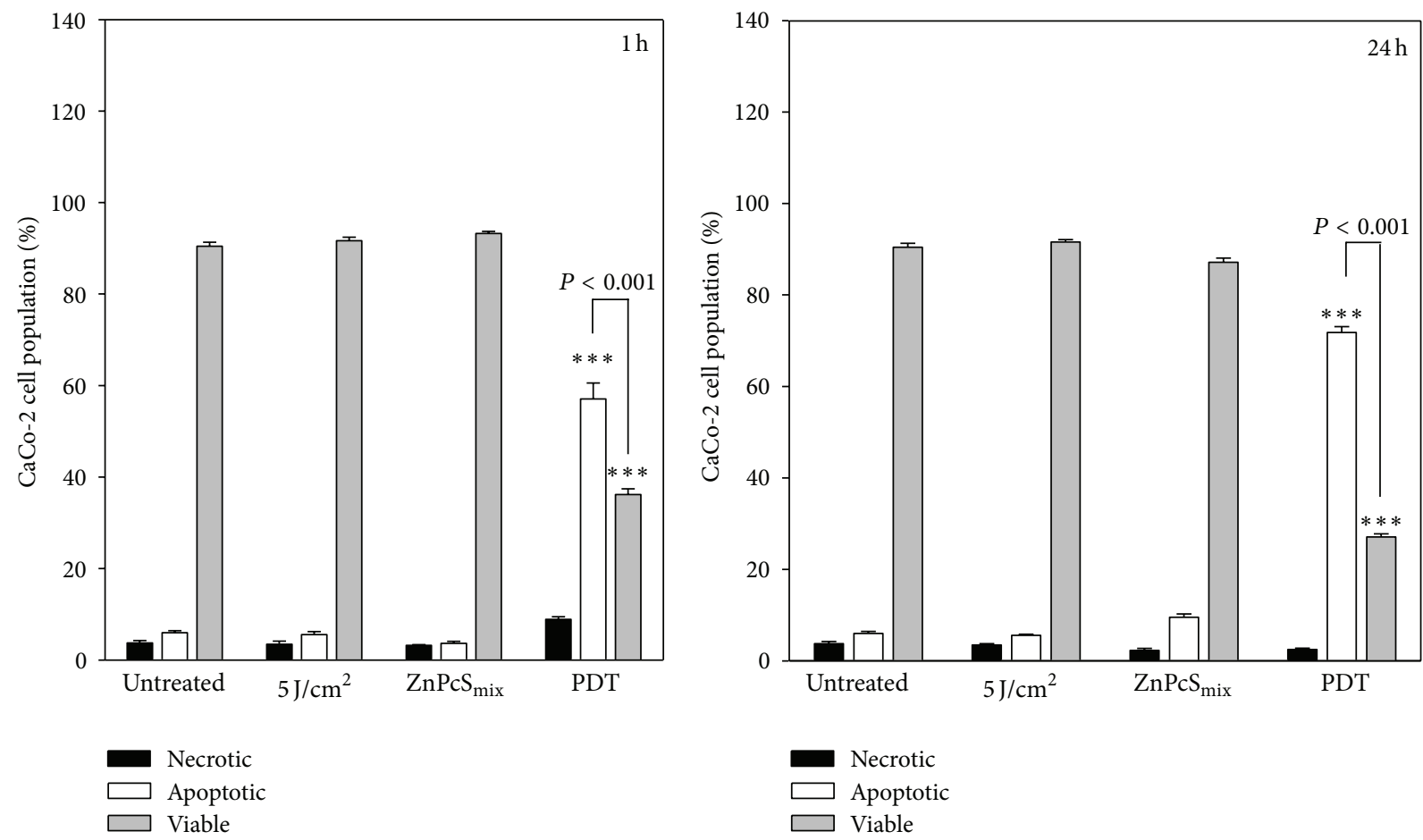

(b)

FIGURE 4: FITC Annexin V staining was used for the assessment of cell death mode in DLD-1 (a) and CaCo-2 (b) cells. Significant differences as compared to untreated cells are shown as ${ }^{* * *} P<0.001$. After $24 \mathrm{~h}$, there was a significant increase in the percentage of apoptotic cell population compared to $1 \mathrm{~h}$ incubation in PDT treated DLD-1 cells (a). PDT treated CaCo-2 cells (b) had a significantly increased apoptotic population percentage after both 1 and $24 \mathrm{~h}$ incubation compared to their respective viable or necrotic cell population percentage $(P<0.001)$.

subcellular organelle is responsible for dissemination of cell death signals.

\section{Conclusion}

Despite the fact that the same PS was used on two different colorectal cancer cells, these cell lines responded differently.
It is evident that the CaCo-2 cells are more susceptible to PDT than the DLD- 1 cells. This could be explained by the different cancer stages that these cells are in CaCo-2 cells are at Duke's B stage (well differentiated, less tumourigenic, and invasive), while DLD-1 cells are at Duke's C stage (metastatic and involves one or three regional lymph nodes). Thus the stage of cancer should be taken into consideration when 
conducting such experiments. We hypothesize that $\mathrm{ZnPcS}_{\text {mix }}$ is capable of inducing apoptotic cell death that is promoted by lysosomal photooxidation. The mechanism in which this PS induces cell death needs to be further studied in order to understand how it triggers cell death, from which initiation point cell death is triggered and how the various cancer stages respond to the treatment.

\section{Disclosure}

The material in this paper submitted to International Journal of Photoenergy neither has been published nor is being considered elsewhere for publication.

\section{Conflict of Interests}

The authors indicate that there is no conflict of interests regarding the publication of this paper.

\section{Acknowledgments}

The authors would like to extend our gratitude to the National Research Foundation (NRF), Council for Scientific and Industrial Research (CSIR) of South Africa, and the University of Johannesburg Research Committee (URC) for financial support, as well as the National Laser Centre (NLC), South Africa, for the setup and maintenance of lasers. Thanks are due to Professor Tebello Nyokong (Department of Chemistry, Rhodes University, South Africa) for synthesizing and providing the $\mathrm{ZnPcS}_{\text {mix }}$. DLD-1 cells were kindly donated by Dr. Clem Penny (Department of Medicine, University of Witwatersrand, South Africa).

\section{References}

[1] http://www.cancer.org/Research/CancerFactsFigures/GlobalCancerFactsFigures/global-facts-figures-2nd-ed.

[2] C. C. Pritchard and W. M. Grady, "Colorectal cancer molecular biology moves into clinical practice," Gut, vol. 60, no. 1, pp. 116129, 2011.

[3] A. Millan and S. Huerta, "Apoptosis-Inducing Factor and Colon Cancer," Journal of Surgical Research, vol. 151, no. 1, pp. 163-170, 2009.

[4] G. Wilkes and K. Hartshorn, "Colon, Rectal, and Anal Cancers," Seminars in Oncology Nursing, vol. 25, no. 1, pp. 32-47, 2009.

[5] A. G. Pallis, D. Papamichael, R. Audisio et al., "EORTC Elderly Task Force experts' opinion for the treatment of colon cancer in older patients," Cancer Treatment Reviews, vol. 36, no. 1, pp. 83-90, 2010.

[6] S. Banfi, E. Caruso, L. Buccafurni, R. Ravizza, M. Gariboldi, and E. Monti, "Zinc phthalocyanines-mediated photodynamic therapy induces cell death in adenocarcinoma cells," Journal of Organometallic Chemistry, vol. 692, no. 6, pp. 1269-1276, 2007.

[7] A. P. Castano, T. N. Demidova, and M. R. Hamblin, "Mechanisms in photodynamictherapy: part one-photosensitizers, photochemistry and cellular localization," Photodiagnosis and Photodynamic Therapy, vol. 1, no. 4, pp. 279-293, 2004.

[8] P. Agostinis, K. Berg, K. A. Cengel et al., "Photodynamic therapy of cancer: an update," CA: Cancer Journal for Clinicians, vol. 61, no. 4 , pp. 250-281, 2011.
[9] S. B. Brown, E. A. Brown, and I. Walker, "The present and future role of photodynamic therapy in cancer treatment," The Lancet Oncology, vol. 5, no. 8, pp. 497-508, 2004.

[10] R. R. Allison, G. H. Downie, R. Cuenca, X.-H. Hu, C. J. H. Childs, and C. H. Sibata, "Photosensitizers in clinical PDT," Photodiagnosis and Photodynamic Therapy, vol. 1, no. 1, pp. 2742, 2004.

[11] A. P. Castano, T. N. Demidova, and M. R. Hamblin, "Mechanisms in photodynamic therapy: part three-photosensitizer pharmacokinetics, biodistribution, tumor localization and modes of tumor destruction," Photodiagnosis and Photodynamic Therapy, vol. 2, no. 2, pp. 91-106, 2005.

[12] L. B. Josefsen and R. W. Boyle, "Photodynamic therapy and the development of metal-based photosensitisers," Metal-Based Drugs, vol. 2008, Article ID 276109, 23 pages, 2008.

[13] R. R. Allison and C. H. Sibata, "Oncologic photodynamic therapy photosensitizers: a clinical review," Photodiagnosis and Photodynamic Therapy, vol. 7, no. 2, pp. 61-75, 2010.

[14] D. E. J. G. J. Dolmans, D. Fukumura, and R. K. Jain, "Photodynamic therapy for cancer," Nature Reviews Cancer, vol. 3, no. 5, pp. 380-387, 2003.

[15] N. L. Oleinick and H. H. Evans, "The photobiology of photodynamic therapy: cellular targets and mechanisms," Radiation Research, vol. 150, no. 5, pp. S146-S156, 1998.

[16] S. W. Ryter, P. K. Hong, A. Hoetzel et al., "Mechanisms of cell death in oxidative stress," Antioxidants and Redox Signaling, vol. 9, no. 1, pp. 49-89, 2007.

[17] J. Zawacka-Pankau, J. Krachulec, I. Grulkowski, K. P. Bielawski, and G. Selivanova, "The p53-mediated cytotoxicity of photodynamic therapy of cancer: recent advances," Toxicology and Applied Pharmacology, vol. 232, no. 3, pp. 487-497, 2008.

[18] R. Bhowmick and A. W. Girotti, "Signaling events in apoptotic photokilling of 5-aminolevulinic acid-treated tumor cells: inhibitory effects of nitric oxide," Free Radical Biology and Medicine, vol. 47, no. 6, pp. 731-740, 2009.

[19] M. Zhao, F. Antunes, J. W. Eaton, and U. T. Brunk, "Lysosomal enzymes promote mitochondrial oxidant production, cytochrome c release and apoptosis," European Journal of Biochemistry, vol. 270, no. 18, pp. 3778-3786, 2003.

[20] N. L. Oleinick, R. L. Morris, and I. Belichenko, "The role of apoptosis in response to photodynamic therapy: what, where, why, and how," Photochemical and Photobiological Sciences, vol. 1, no. 1, pp. 1-21, 2002.

[21] A. P. Castano, T. N. Demidova, and M. R. Hamblin, "Mechanisms in photodynamic therapy: part one-photosensitizers, photochemistry and cellular localization," Photodiagnosis and Photodynamic Therapy, vol. 1, no. 4, pp. 279-293, 2004.

[22] J. A. Caruso, P. A. Mathieu, and J. J. Reiners Jr., "Sphingomyelins suppress the targeted disruption of lysosomes/endosomes by the photosensitizer NPe6 during photodynamic therapy," Biochemical Journal, vol. 392, no. 2, pp. 325-334, 2005.

[23] D. Kessel, Y. Luo, P. Mathieu, and J. J. Reiners Jr., "Determinants of the apoptotic response to lysosomal photodamage," Photochemistry and Photobiology, vol. 71, no. 2, pp. 196-200, 2000.

[24] C. De Duve, "Lysosomes revisited," European Journal of Biochemistry, vol. 137, no. 3, pp. 391-397, 1983.

[25] L. Emert-Sedlak, S. Shangary, A. Rabinovitz, M. B. Miranda, S. M. Delach, and D. E. Johnson, "Involvement of cathepsin $\mathrm{D}$ in chemotherapy-induced cytochrome c release, caspase activation, and cell death," Molecular Cancer Therapeutics, vol. 4, no. 5, pp. 733-742, 2005. 
[26] A. Minarowska, Ł. Minarowski, A. Karwowska, and M. Gacko, "Regulatory role of cathepsin D in apoptosis," Folia Histochemica et Cytobiologica, vol. 45, no. 3, pp. 159-163, 2007.

[27] L. P. Deiss, H. Galinka, H. Berissi, O. Cohen, and A. Kimchi, "Cathepsin D protease mediates programmed cell death induced by interferon- $\gamma$, Fas/APO- 1 and TNF- $\alpha$," The EMBO Journal, vol. 15, no. 15, pp. 3861-3870, 1996.

[28] G. Kroemer and M. Jaatella, "Lysosomes and autophagy in cell death control," Nature Reviews Cancer, vol. 5, pp. 886-897, 2005.

[29] A.-C. Johansson, H. Steen, K. Öllinger, and K. Roberg, "Cathepsin D mediates cytochrome $\mathrm{c}$ release and caspase activation in human fibroblast apoptosis induced by staurosporine," Cell Death and Differentiation, vol. 10, no. 11, pp. 1253-1259, 2003.

[30] T. G. Gantchev, J. E. Van Lier, and D. J. Hunting, "Molecular models of zinc phthalocyanines: semi-empirical molecular orbital computations and physicochemical properties studied by molecular mechanics simulations," Radiation Physics and Chemistry, vol. 72, no. 2-3, pp. 367-379, 2005.

[31] H. Barr, P. Chatlani, C. J. Tralau, A. J. MacRobert, P. B. Boulos, and S. G. Bown, "Local eradication of rat colon cancer with photodynamic therapy: correlation of distribution of photosensitiser with biological effects in normal and tumour tissue," Gut, vol. 32, no. 5, pp. 517-523, 1991.

[32] J. H. Woodhams, A. J. MacRobert, M. Novelli, and S. G. Bown, "Photodynamic therapy with WST09 (Tookad): quantitative studies in normal colon and transplanted tumours," International Journal of Cancer, vol. 118, no. 2, pp. 477-482, 2006.

[33] A. Ogunsipe and T. Nyokong, "Photophysical and photochemical studies of sulphonated non-transition metal phthalocyanines in aqueous and non-aqueous media," Journal of Photochemistry and Photobiology A, vol. 173, no. 2, pp. 211-220, 2005.

[34] S. L. Manoto, P. R. Sekhejane, N. N. Houreld, and H. Abrahamse, "Localization and phototoxic effect of zinc sulfophthalocyanine photosensitizer in human colon (DLD-1) and lung (A549) carcinoma cells (in vitro)," Photodiagnosis and Photodynamic Therapy, vol. 9, no. 1, pp. 52-59, 2012.

[35] A. Saratse and K. Pulkki, "Morphologic and biochemical hallmarks of apoptosis," Cardiovascular Research, vol. 45, pp. 528537,2000 .

[36] H. Wiseman and B. Halliwell, "Damage to DNA by reactive oxygen and nitrogen species: role in inflammatory disease and progression to cancer," Biochemical Journal, vol. 313, no. 1, pp. 17-29, 1996.

[37] J. M. Matés and F. M. Sanchez-Jimenez, "Role of reactive oxygen species in apoptosis: implications for cancer therapy," The International Journal of Biochemistry \& Cell Biology, vol. 32, no. 2, pp. 157-170, 2000.

[38] G. Quiogue, S. Saggu, H.-I. Hung et al., "Signaling from lysosomes enhances mitochondria-mediated photodynamic therapy in cancer cells," in Photodynamic Therapy: Back to the Future, vol. 7380 of Proceedings of SPIE, pp. 1-8, Seattle, Wash, USA, June 2009.

[39] A.-C. Johansson, H. Appelqvist, C. Nilsson, K. Kågedal, K. Roberg, and K. Öllinger, "Regulation of apoptosis-associated lysosomal membrane permeabilization," Apoptosis, vol. 15, no. 5, pp. 527-540, 2010.

[40] M. E. Rodriguez, P. Zhang, K. Azizuddin et al., "Structural factors and mechanisms underlying the improved photodynamic cell killing with silicon phthalocyanine photosensitizers directed to lysosomes versus mitochondria," Photochemistry and Photobiology, vol. 85, no. 5, pp. 1189-1200, 2009.
[41] D. Kessel and Y. Luo, "Intracellular sites of photodamage as a factor in apoptotic cell death," Journal of Porphyrins and Phthalocyanines, vol. 5, no. 2, pp. 181-184, 2001.

[42] H. L. Persson, "Iron-dependent lysosomal destabilization initiates silica-induced apoptosis in murine macrophages," Toxicology Letters, vol. 159, pp. 124-133, 2005.

[43] P. Mroz, J. Bhaumik, D. K. Dogutan et al., "Imidazole metalloporphyrins as photosensitizers for photodynamic therapy: role of molecular charge, central metal and hydroxyl radical production," Cancer Letters, vol. 282, no. 1, pp. 63-76, 2009.

[44] T. Kurz, A. Terman, B. Gustafsson, and U. T. Brunk, "Lysosomes in iron metabolism, ageing and apoptosis," Histochemistry and Cell Biology, vol. 129, no. 4, pp. 389-406, 2008.

[45] S.-M. Chiu, L.-Y. Xue, M. Lam et al., "A requirement for bid for induction of apoptosis by photodynamic therapy with a lysosome- but not a mitochondrion-targeted photosensitizer," Photochemistry and Photobiology, vol. 86, no. 5, pp. 1161-1173, 2010.

[46] U. Repnik and B. Turk, "Lysosomal-mitochondrial cross-talk during cell death," Mitochondrion, vol. 10, no. 6, pp. 662-669, 2010.

[47] U. T. Brunk, H. Dalen, K. Roberg, and H. B. Hellquist, "Photo-oxidative disruption of lysosomal membranes causes apoptosis of cultured human fibroblasts," Free Radical Biology and Medicine, vol. 23, no. 4, pp. 616-626, 1997.

[48] U. T. Brunk and I. Svensson, "Oxidative stress, growth factor starvation and Fas activation may all cause apoptosis through lysosomal leak," Redox Report, vol. 4, no. 1-2, pp. 3-11, 1999.

[49] J. J. Reiners Jr., J. A. Caruso, P. Mathieu, B. Chelladurai, X.-M. Yin, and D. Kessel, "Release of cytochrome $\mathrm{c}$ and activation of pro-caspase-9 following lysosomal photodamage involves bid cleavage," Cell Death and Differentiation, vol. 9, no. 9, pp. 934944, 2002.

[50] J. Kim, H. Fujioka, N. L. Oleinick, and V. E. Anderson, "Photosensitization of intact heart mitochondria by the phthalocyanine Pc 4: correlation of structural and functional deficits with cytochrome c release," Free Radical Biology and Medicine, vol. 49, no. 5, pp. 726-732, 2010. 

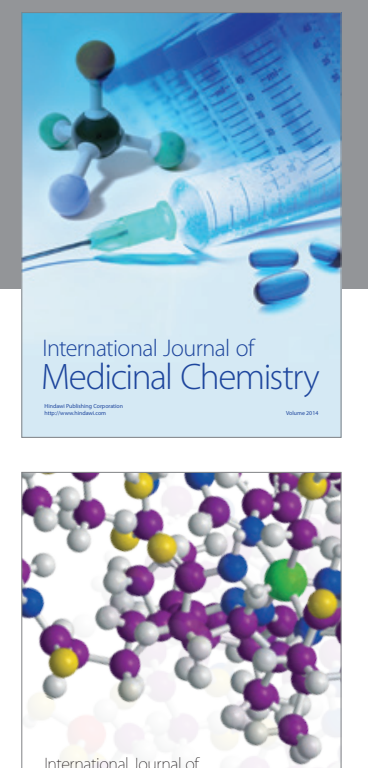

\section{Carbohydrate} Chemistry

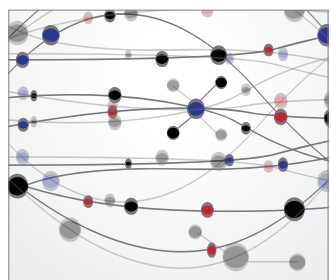

The Scientific World Journal
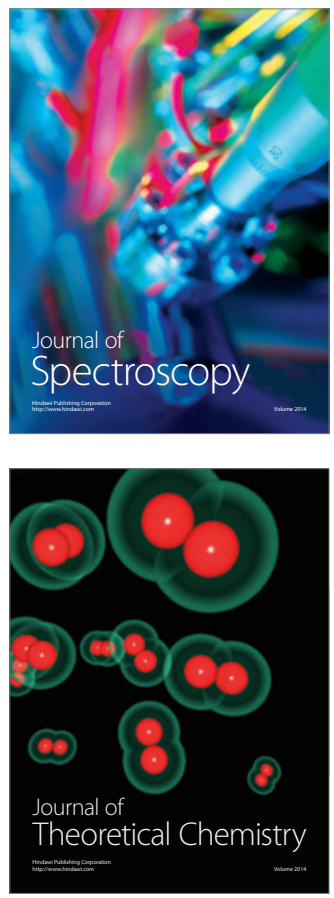
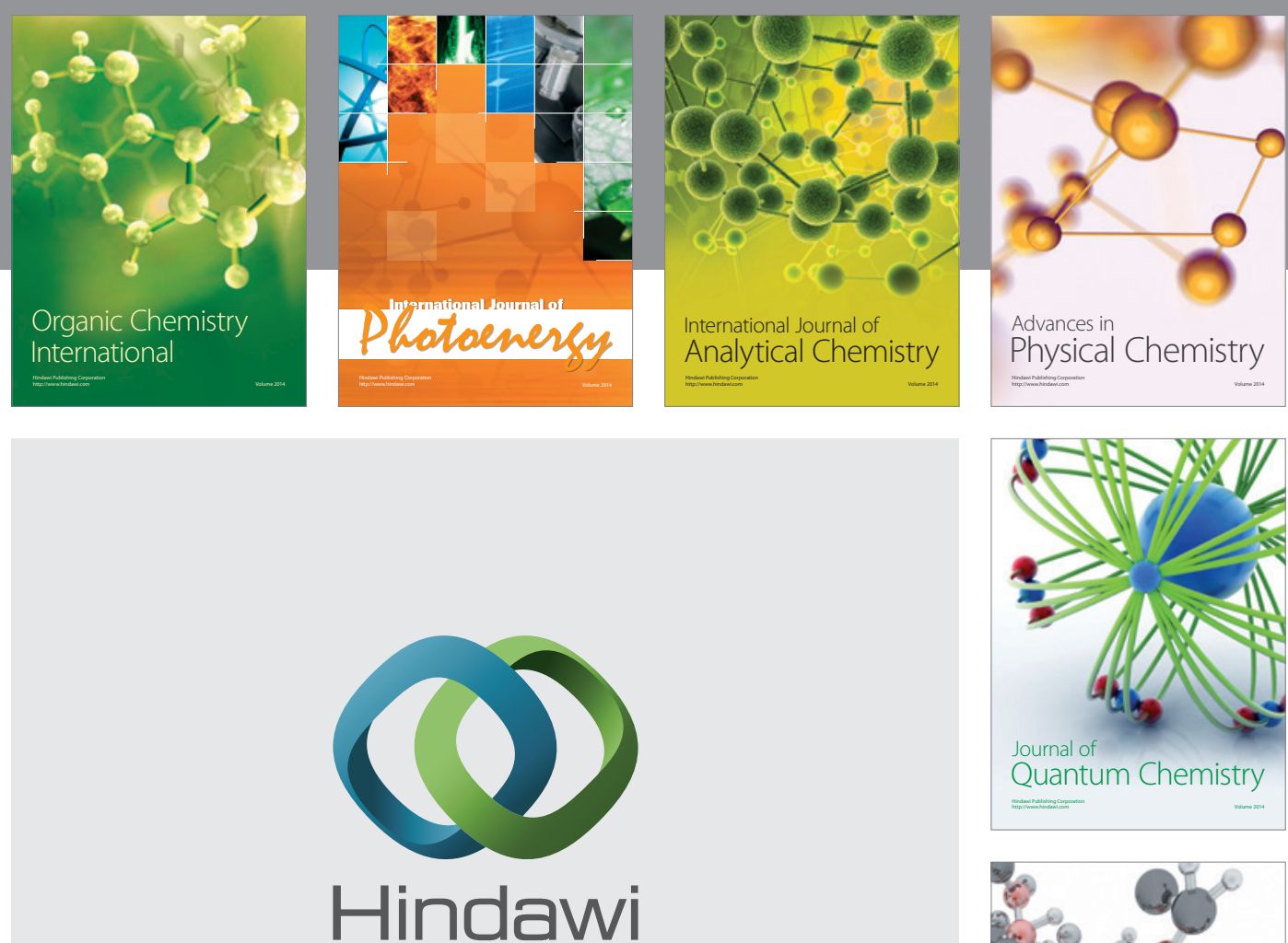

Submit your manuscripts at

http://www.hindawi.com

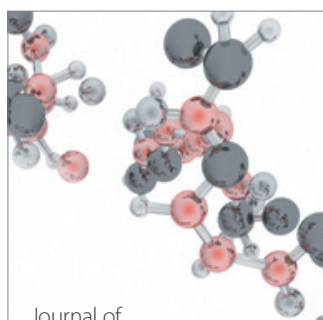

Analytical Methods

in Chemistry

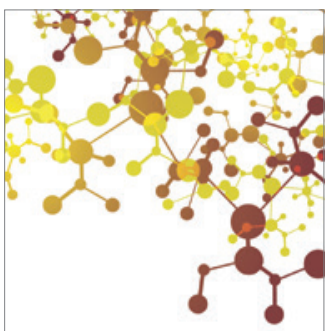

Journal of

Applied Chemistry

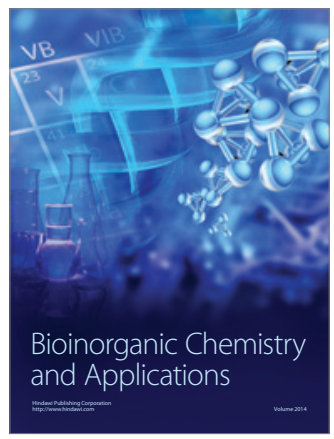

Inorganic Chemistry
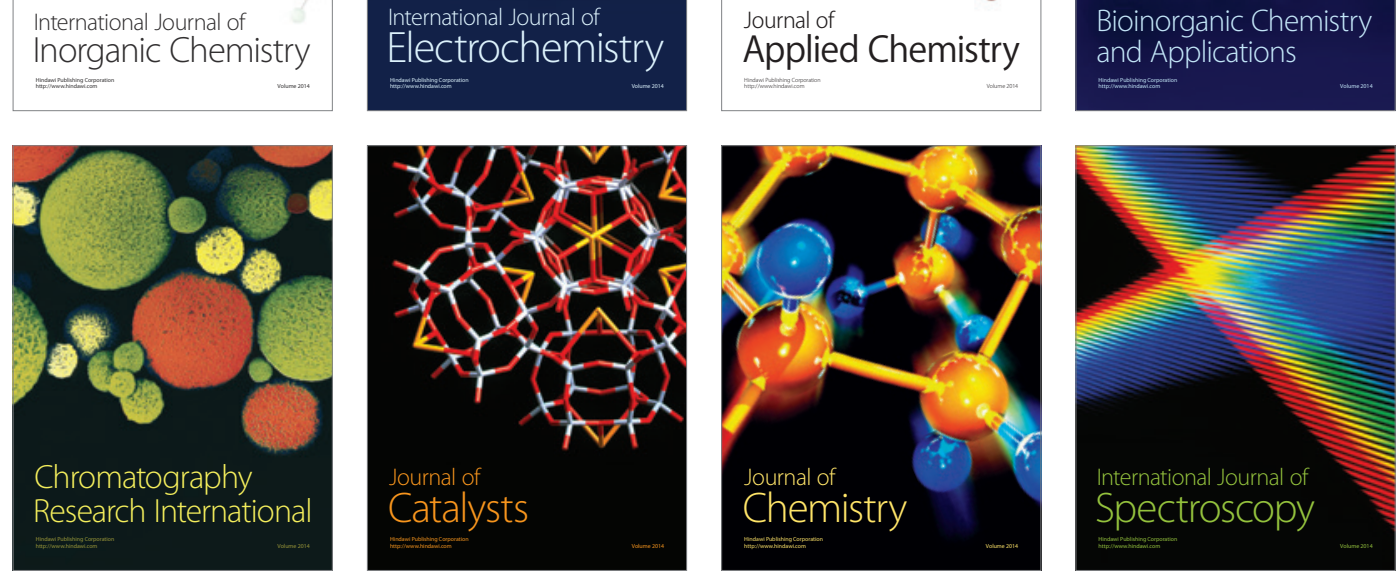